\title{
Women, priests and patriarchal ecclesial spaces in the Anglican Church of Southern Africa: On 'interruption' as a transformative rhetorical strategy
}

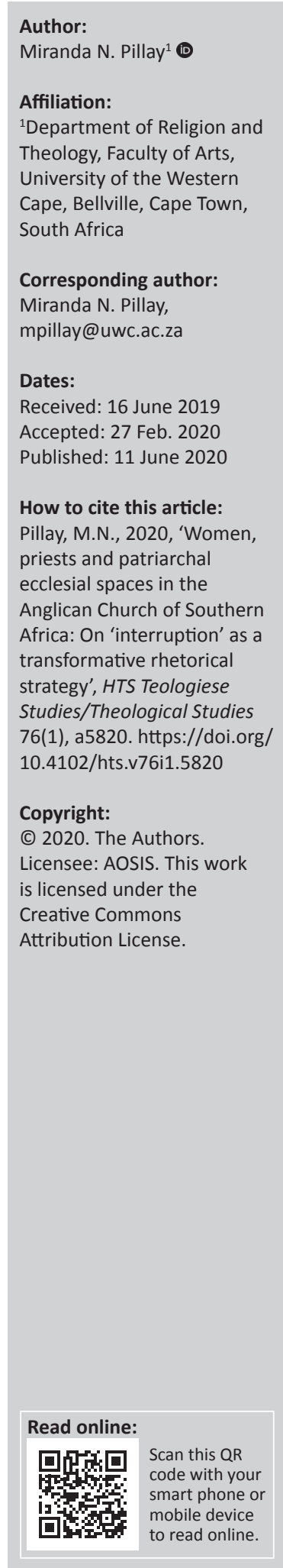

In spite of the presence of women in previously male-dominated ecclesial spaces, patriarchal normativity continues to be re-inscribed through the reproduction of knowledge, which sustains skewed gender power relations amongst the clergy. This was a case in point when a newly ordained woman priest in the Anglican Church of Southern Africa was recently addressed as, and given the official title, 'mother' during the vestment ritual at a church service where she was to celebrate the Eucharist for the first time. This while the male priests present had retained the title 'father' without any critical reflection on the male-headship theology it perpetuates. If one considers that the ordination of women has opened the possibility for them to celebrate the Eucharist, which gives authority to preside at (or head) the 'Table', then one has to be mindful of the subtle ways in which language is used to regulate the production and reproduction of gender bias in a patriarchal system. Being the guest preacher at the celebratory service of this former Ethics and Theology student, I could do no other but interrupt the sermon I had prepared. In this article, I argue that interruption is a helpful theoretical concept - both as a transformative rhetorical strategy in the interpretation of biblical texts and also as an act of resisting discourses and practices that uphold and re-inscribe patriarchal norms. I will approach the hermeneutical concept of interruption from what I call a feminist theo-ethical perspective.

Keywords: Women priests; Anglican church; Patriarchal normativity; Feminist theo-ethical perspective; Intertextual reading; Interruption; Hermeneutics.

\section{Introduction}

The following statement, made by Mr David Mokobe, was posted on the ACSA 25th Anniversary of Women Ordination to the Priesthood Facebook page, 'if God meant women to be priests he [sic] would have done so from the beginning. Men must be a symbol of Christ at the Eucharist. ${ }^{1}$

This was one of the reasons given at the 1992 Provincial Synod of the Anglican Church of Southern Africa (ACSA) - then known as the Church of the Province of Southern Africa (CPSA) - for why women should not be ordained. ${ }^{2}$ While the statement in the quote above was made by a male representing the laity, it was clearly also 'the mind' of a bishop who at the time argued that '...no part of the New Testament testifies that a woman could be, in a public and authorised way, the representative of Christ' (cf. Pillay 2017:1). So, it is not surprising that (the then) Dean of St George's Cathedral, Colin Jones, made a strong argument against the idea that 'male character as distinct from female character is necessary' for priesthood when introducing the resolution asking the Synod to give its approval to the ordination of women ${ }^{3}$. However, a decision was taken in favour of the ordination of women. ${ }^{4}$

For many South Africans, the 79\% vote, which would allow women access to a male-dominated ministry, echoed the 'then currents of change and rhetoric of freedom' and transformation in

1.This was the view of Mr David Mokobe, a lay representative at the 1992 Synod of the Anglican Church of Southern Africa, during a debate before the vote on whether women should be 'allowed' to be ordained priests in the church. See https://www.facebook.com/ pages/category/Religious-Organization/ACSA-25th-Anniversary-of-Women-Ordination-to-the-Priesthood-227667387641081/, posted 03 July 2017, viewed 09 August, 2019; cf. Pillay (2017:1).

2.A topic that has been discussed, debated, analysed and reported on since 1970. For a historical overview of the 'movement for the ordination of women' in the Anglican Church, see Swart-Russell and Draper (1991); cf. Pillay (2017:2).

3.See the Facebook post, titled, 'Hear God calling women', at https://www.facebook.com/pages/category/Religious-Organization/ACSA25th-Anniversary-of-Women-Ordination-to-the-Priesthood-227667387641081/ (viewed 09 August 2019).

4.In favour of allowing the ordination of women as priests in ACSA (then CPSA): $84 \%$ laity; $74 \%$ clergy; $78 \%$ bishops (see https://www. facebook.com/pages/category/Religious-Organization/ACSA-25th-Anniversary-of-Women-Ordination-to-the-Priesthood227667387641081/ (viewed 09 August 2019).

Note: Special collection entitled Ethics, education and social justice, sub-edited by John Klaasen (UWC) 
apartheid South Africa (Pillay 2017:1). ${ }^{5}$ The decision to include women in this male-dominated ecclesial space echoed the general mood for change in the country. It was 1992 - a time of political transition - two years after the release of Nelson Mandela and two years before South Africa's first democratic election. Besides it being a timely move by the church, the ordination of women was also considered to be a move in the right direction - towards transforming oppressive social structures. Over the past quarter century of women in priesthood in ACSA, many efforts have been made to ensure that women are represented in previously male-dominated spaces in the church as workplace, but very little has been done regarding transforming the dominant male ethos in ecclesial spaces. This is a reflection of the former South African constitutional judge Albie Sachs's (1998:10) observation that, '[i]t is a sad fact that one of the few profoundly non-racial institutions in South Africa is patriarchy'.

As mentioned earlier, in December 2018, a newly ordained woman priest in the ACSA was addressed as, and given the official title, 'mother' during the vestment ritual at a church service where she was to celebrate the Eucharist for the first time. This social reality emphasises the ongoing effects of patriarchy in previously male-dominated ecclesial spaces, where male priests are addressed as 'father' without any critical reflection on the male-headship theology such language perpetuates. In the words of Cannon (1995:110), '[w] hat to do with such sexist paradigms?'

What was I to say? What was I to do? There I stood - aware that I could do no other but interrupt the sermon I had prepared for the occasion. By reflecting on my experience there, I will discuss interruption as a transformative rhetorical strategy. The hermeneutical strategy used in this article is guided by what I call a feminist theo-ethical perspective. ${ }^{6}$ My intension here is to illustrate that interruption of the 'usual' way things are said and done could turn ecclesial spaces into 'sites of resistance', ${ }^{7}$ which then become sites of transformation. The idea of resistance is not unfamiliar to ACSA. ${ }^{8}$ Thus, I will explore interruption as a strategy to open avenues for new ways of knowing that could lead to transforming gender-normative practices. Firstly, I will describe why interruption of patriarchal normativity is an ongoing social justice issue for the church and the wider South African society.

5.Although the vote at the 1989 Synod of ACSA (the CPSA) was $61 \%$ in favour of the ordination of women, back then it did not comply with the two-thirds majority ordination of women, back then it
necessary for a 'controversial issue'.

6.My feminist theo-ethical perspective stems from a concern for social justice as a Christian South African woman of mixed race and as one who has come to identify and experience that the subtle and obscure forms of paternalistic/patriarchal powe drive racism, sexism and classism, which maintain supremacy. As a biblical scholar, have discovered that many injustices inherent in these 'isms' find justification through particular readings of the Christian Bible (Pillay 2012).

7.A term I borrowed from Bell Hooks (1994:21).

8.In 1957, the Archbishop of ACSA (then known as the Church of the Province of South Africa), Geoffrey Clayton, together with the bishops he had summoned to a meeting made a brave stand against the apartheid law that 'made it nearly impossible for any black person to worship in any white areas'. They wrote a letter to the then Prime Minister in which they publicly rejected the law. Every parish within ACSA Prime Minister in which they publicly rejected the law. Every parish within ACSA
received a copy of the letter together with an appeal for parishes to 'ignore the law' received a copy of the
(Prozesky 1990:272).

\section{On interrupting patriarchal normativity}

The premise of my argument is that, in spite of the presence of women in previously male-dominated ecclesial spaces, patriarchal normativity is re-inscribed through the reproduction of knowledge, which sustains skewed gender power relations amongst the clergy. It is my view that addressing women priests as 'mother' sanctifies patriarchal hierarchy and perpetuates the inherent patriarchal nature of priesthood. ${ }^{9}$ Moreover, the 'exclusion of women from priesthood, as well as the theological shifts which persuaded otherwise, has not been dealt with on clerical or grassroots' spheres of the church (Pillay 2017:2). Instead, many parishioners still look up to 'father', ${ }^{10}$ and male priests close ranks, while many women priests seek authentic ways to navigate their ministry (intentionally or not) through patriarchal normative morasses in ecclesial spaces.

When patriarchy is justified by headship theology, it is given a double-banded halo - a religio-cultural halo. A rise in 'conservative' religious movements often associated with nationalism or right-wing politics in recent times has resulted in the justification of male headship in many church circles. ${ }^{11}$ Thus, challenging patriarchy is often 'seen as an attempt to undermine Christian' values 'or African traditions' (Pillay 2017:8). Any attempt to address this view leads to further patriarchal re-inscription - albeit subtle or sometimes unintentional. For example, according to Ezra Chitando (2015:277), African nationalists have resisted the call for gender transformation because 'it is a Western imposition'. 'As defenders of African culture', men 'are more likely to embrace the quest for gender justice when it has been demonstrated that their own value system leads to gender justice'. ${ }^{12}$ As I have pointed out on a previous occasion, Chitando's argument 'smacks of androcentrism which drowns the "voice" of African women theologians' who have, for many years, articulated their concerns 'about the dehumanizing effects of patriarchy on women and men' (Pillay 2017:8). ${ }^{13}$ Many African women theologians have,

9.Sometimes, it renders women priests 'invisible' in the presence of male colleagues because many parishioners still look up to the 'father', as some women priests whose husbands are priests have told me. I do not profess to speak for or on behalf of women priests. Rather, I speak and write as a woman of faith who is concerned about the (ab)use of power to justify/sanctify any form of discrimination. I am also aware that there are women priests in ACSA who do not feel discriminated against.

10.As previously cited (Pillay 2017:6) in a Facebook Post, a male priest in the Anglican Church of Southern Africa stated, '[s]omething I must relay to you ... so funny and beautiful ... someone came to my church office just now to make an appointment and with the person is a child not more than 4 years old ... after greeting them both and blessing the child they left and immediately returned ... the adult looking with and blessing the child they left and immediately returned ... the adult looking with (see https://www.facebook.com/leon.canrheede, posted on 03 July 2017).

11.See Mighty men, mighty families: A pro-family Christian movement to (re)enforce patriarchal control? (cf. Pillay 2015b, 2017:8).

12.To this end, Chitando calls for a 'refining' of the African concept of Ubuntu and argues that if this concept is 'divested of its patriarchal packaging', it could serve as a resource for the struggle against patriarchal violence. However, Chitando (2015:276-279) did not suggest any strategies for 'stripping' Ubuntu of its culturally inherent patriarchy (cf. Pillay 2017:8)

13. Here, I refer in particular to the work of the Circle of African Women Theologians, A vision and initiative of Mercy Amba Oduyoye, The Circle, as it has come to be known, was inaugurated in 1989. Conversations had already begun in 1980 at a meeting of African women theologians in Ibadan. For a brief overview of the history of The Circle, see Oduyoye (1997:1-6). 
over the years, repeatedly argued that major areas of life, including sexuality, health, family, religion, education, economy, politics, etc., are shot through with conflicting interests and hierarchies of power and privilege along gender lines. Moreover, his (Chitando's) argument 'justifies the position of men as the gatekeepers of patriarchy' (Pillay 2017:8). As part of the gate-keeping strategy, women are often co-opted into previously male-dominated spaces to maintain the gender status quo.

Thus, while the ordination of women has given them new possibilities of leadership, there has been little signs of transforming previously male-dominated ecclesial spaces. The social reality of ecclesial spaces emphasises the ongoing effects of patriarchy as an institutional force. New possibilities - liberative possibilities - are thwarted by the social force inherent in hyper-normative patriarchy. Its invisible power is pervasive, but its effects in reproducing gender biases that are systemic and social are real. Moreover, not only do arguments that perpetuate and defend male headship render patriarchy 'palatable' (Nadar 2009:55), but it also masquerades as being benevolent towards women. I concur with Young (1990:40) who argued that domination does not only mean the 'exercising of tyranny by a ruling group’ (cf. Pillay 2015:68).

The disadvantage and injustice some people suffer is not because a tyrannical force coerces them but because of the 'everyday practices of well-intentioned liberal society' (Young 1990:41). Young (1990) explained that oppression and domination also refer to:

$[T]$ he vast and deep injustices people suffer as a consequence of often unconscious assumptions and reactions of well-meaning people in ordinary interactions, media and cultural stereotypes, and structural features of bureaucratic hierarchies and market mechanisms. (p. 41)

Young (1990) also pointed out that oppression in all its guises is the systemic constraints placed on a group that is structural rather than the result of choices. This, she argues, is because the causes of oppression are 'embedded in unquestioned norms, habits and symbols and in the assumptions underlying institutional rules and the collective consequences for following those rules' (Young 1990:45).

Thus, it is imperative that women (and men) (Pillay 2003):

[W] ho seek to make sense of the life of faith and those who envisage radical transformation, reflect critically and systematically on structures and practices within the church and society that continue to uphold patriarchal symbols and hierarchical relationships. (p. 148)

\section{As Mercy Amba Oduyoye (2009) observed:}

The church's structures are fixed, the church's orders are fixed, the church's ministries are fixed, and none of these seem flexible enough to admit women's visions, women's skills and women's offerings of charismata: God-given gifts the church and the world desperately need. (p. 30)
I want to argue that 'interrupting' the 'natural order of things ${ }^{\prime 14}$ in ecclesial spaces is putting such critical reflection into practice - albeit at a risk.

The decision by the Anglican Church to admit women to the priesthood gives them the authority to preside at (or head) the 'Table'. Therefore, one has to be mindful of the subtle ways in which language is used to regulate the production and reproduction of gender bias under a system of patriarchy. Moreover, it is necessary to not only expose or uncover or 'cut into' 15 patriarchal-imposed knowledge by interrupting normative ideas and practices but also for ecclesial spaces to be transformed. In Teaching to Transgress, Bell Hooks (1994:22) noted that 'resistance lies in self-conscious engagement with dominant, normative discourses ${ }^{16}$ and in active creation of oppositional analytic and cultural spaces'. I will now turn to interruption as a transformative strategy. Then I hold Luke's annunciation narrative as an example (and possible ecclesial resource) of interrupting gender-normative ideas and practices.

\section{Interruption: On resisting and transforming dominant male culture}

According to Cannon (1994):

When strong, positive, God-centred women confront their male counterparts, they are usually afforded a subtle, institutionalised option to conform to whatever those in power have defined as normative. (p. 60)

The fact whether women (and other marginalised groups) confront or conform to dominant male culture in ecclesial spaces depends on whether they perceive all knowledge to be absolute. ${ }^{17}$ Those who conform most likely perceive knowledge and authority to be vested in powerful and 'knowing others' from whom one is expected to learn; those who confront most likely perceive knowledge to be voiced by a prevailing dominant culture and that 'truth' is understood to be contextual.

In the latter instance, received knowledge is recognised as tentative - not absolute. This opens avenues for alternative 14.See Pillay (2003).

15.Claassens (2008:55), referring to the work of Levinas and Derrida, described 'cutting into' as interrupting the handed-down pattern in a text during the interpretive process.

16.An emphasis on language and discourse is a common theme in the feminist critique of the 'maleness of reason' (Heckman 1990:30). In Gender and Knowledge, critique of 'maleness of the ' Heckman (199) onserions on language and discourse has thange and ower. Moreover, linguistic practice binarism. Binarism maintains two distinct, opposite and disconnected forms of masculine/feminine and perpetuates gender stereotyping. It also ignores the realities of those who identify as lesbian, gay, bisexual and transgender.

17.As noted elsewhere, 'based on a study relating to the experiences of a diverse group of women, Belenky et al. (1986) identified five knowledge perspectives that shape the major ways women (irrespective of class, race or ethnic background) think about themselves, authorities, truth and life options: (1) Silence - a position of not knowing in which the person feels voiceless, powerless and mindless; (2) Received knowing - a position at which knowledge and authority are construed as outside the self and invested in powerful and "knowing others" from whom one is expected to learn; (3) Subjective knowing - in which knowing is personal, private expected to learn; (3) Subjective knowing - in which knowing is personal, private and based on intuition and/or feeling states rather than on thought and articulated ideas that are defended with evidence; (4) Procedural knowing - the position at which techniques and procedures for acquiring, validating and evaluating knowledge claims are developed and honoured; (5) Constructed knowing - the position at which truth is understood to be contextual, knowledge is recognized as tentative, not absolute; and it is understood that the knower is part of (and constructs) the known' (Pillay 2015:67-68). 
liberative interpretations of what is handed down as normative. Such creative possibilities present themselves if 'the usual' is interrupted and creative, alternative understandings are explored. As a persuasive strategy, interruption goes against what is expected and creates disorder by resisting what has come to be understood as the natural order of things. ${ }^{18}$ This, I think, serves as an invitation to engage others in meaningmaking and conduit for the creation of new knowledge. Such an interpretive possibility is not a foreign enterprise because it is already present in the biblical tradition as argued by the South African biblical scholar, Juliana Claassens. In an article, 'Interrupting God-language: Rethinking the image of God as liberator in Isaiah 42', Claassens (2008:55-59) made a reference to the translated works of Derrida and Levinas on the question of 'what it means to be responsible readers of the text'. She observed that interruption as an hermeneutical tool involves a 'cutting into' the text as well as re-stitching it with a thread already present in the text itself (Claassens 2008:55).

Claassens (2008) noted that the motivation to interrupt the natural tendency of discourse, which becomes 'fixed or frozen over time', comes from an encounter with the other. Thus, it is the lived reality of the marginalised 'other' that moves the interpreter to interrupt normative cultural practices exhibited in biblical texts and seek new insights that are transformative. But as Claassens (2008:57) rightly argued, 'it is important to note that these voices of the other that may be responsible for new insight and transformation [may] also show up within the text'. She illustrated this point by showing how the normative male reference to God is interrupted by the image of God as woman in Isaiah 42 (Claassens 2008:59-66).

My understanding of Claassen's (2008) argument is that the inner-texture of that particular text exhibits both an interruption of the normative and a counter-culture alternative.

I want to argue that, where patriarchal normativity is reinscribed in the text, an intertextual reading may also serve to interrupt and transform patriarchal normative patterns in the Bible. ${ }^{19}$ Because the Bible itself is a multi-cultural, multi-vocal document with writings that span many centuries and cultures, an understanding of the dynamics of intertextuality is a helpful reading strategy to distinguish between elements / ideas in the text that are historically contingent and those that transcend time and space. ${ }^{20}$

Secondly, intertextuality helps us see the progressive and unfolding nature of the Bible. ${ }^{21}$ Thirdly, intertextuality helps

18.As Bell Hooks (1994:22) noted, 'resistance lies in self-conscious engagement with dominant, normative discourses and representations and in active creation of oppositional analytic and cultural spaces'.

19.Inter-texture and inner-texture are two of five textures of texts that Robbins (1996) introduced in his seminal work on socio-rhetorical interpretation (see also Pillay 2008a).

20.For example, if we consider (from a wide-angled canonical view) the theme of marriage, we will see that there are multiple ways in which marriage itself is understood in various texts. Some texts accept polygamy as a given, while other texts assume and presuppose monogamy - a cultural diversity sanctioned by the texts assume and

21.Through the life, death and resurrection of Jesus and the coming of the Holy Spirit at the Pentecost, we are given critical vantage points from which the biblical witness is reread and reframed. We see how 'certainties' embodied in identity us to differentiate between those patterns in Scripture that are normal or descriptive and those patterns that are normative or prescriptive. For example, it is normal in the context of the biblical texts for men to be in a position of leadership, but there are also exceptions (interruptions) to that normal pattern, which raise the question of whether the normal (or typical) pattern should also be understood to be normative (or prescriptive).

Thus, as also poignantly observed by Claassens (2008), the Bible itself may exhibit new insights that are liberating and transformative.

What follows is an example of how intertextual reading allows for the 'cutting into' the re-inscription of patriarchal normativity in Matthew 1:18-25 when read against Luke's account of the annunciation narrative.

\section{Luke's Mary interrupts Matthew's Joseph}

Matthew 1:18-25 was the appointed lectionary reading for 18 December 2018 - the day I preached at the occasion of the woman priest celebrating the Eucharist for the first time. In preparing the sermon, it became clear to me that I could not only focus on Matthew's version of the annunciation. To do this would be to make Joseph the subject and Mary the object. or as Mary Daly (1973:26) would say, 'non-being'.22 Thus, an intertextual approach to the angel Gabriel's visitation to Joseph (Mt 1:18-25) and Mary (Lk 1:26-38) had to be included in the exegetical task.

While the name of Mary (Jesus' mother) appears eight times in Matthew - five times by name $(1: 16,18,20 ; 2: 11 ; 13: 55)$ and reference to 'the child and his mother' is made four times $(2: 13,14,20,21)$, she is merely spoken about. In these Matthean texts, she does not speak and is also not spoken to. Not once is Mary an active subject in the Gospel of Matthew..$^{23}$ As I have mentioned elsewhere, 'the Matthean Gospel constructs a symbolic universe that is androcentric and encodes the patriarchal constructs present in its historical sociocultural location' and 'that the text creates a world in which the male norm is synonymous with being human' (Pillay 2015:6). This normativity finds expression in the grammatical and narrative strategies of a text that ignores woman as subject/be-ing. ${ }^{24}$ If, as readers of the text, we ignore this observation, we are complicit in re-inscribing the normative patriarchy exhibited

markers such as kosher eating and circumcision are re-envisioned as culturally particular and not God-ordained

22.Besides, with Christmas approaching, I could not imagine a nativity scene without Mary exclaiming 'How will this be?' (Lk 1:34).

23. One must acknowledge that for Matthew, Mary is a background prop in a patriarchal normative society - even though some feminist scholars have identified the liberative potential of this Gospel. For example, see Pillay (2015)

24.For example, 'in the Sermon on the Mount, there are repeated instances of male exclusive terms such as son/s, man/men, brother, father and he $(5: 13,15,19,22,45$; $6: 1,16,18 ; 7: 3-5,8,9,12,21)$. This exclusive reference to males reflects a narrative world from which women appear to be absent and it considers the experience of sonship, fatherhood, and brotherhood to be universal and appropriately adequate for the expression of human experience' (Pillay 2015:6). 
in the text. ${ }^{25}$ It is thus necessary to 'cut into' the text to interrupt the dominant male voice.

To also make Mary the subject in the annunciation narrative, it is important to hear Luke's Mary speak. ${ }^{26}$ Besides, I cannot recall ever seeing a nativity play that does not include the characters or voices of both Mary and Joseph. Neither one that excludes the wise men following the star in the East only found in Matthew's Gospel (2:1-12), nor one that excludes the shepherds following the instructions of the angel only found in Luke's Gospel (2:8-15). Thus, both Matthew's Joseph and Luke's Mary are needed to do some mending when we 'cut into' the cloth of patriarchy in our search of alternative interpretations that are liberative to women (and men).

By including Luke's account of the annunciation in my exegetical work in the sermon preparation, I cut into the Matthean narrative and used a 'loose thread' already present in the Bible tradition to 're-stitch' the cloth (Claassens 2008:55). As Vernon Robbins (2006) argued, a text is like a tapestry, which reveals different patterns - depending on which angle one views it from and what interpretive strategies one chooses to use. This is evident in the excerpt from my sermon:

The focus of today's Gospel reading (Mt 1:18-25) is on Joseph. Matthew does not tell us how Joseph came to know about Mary's pregnancy 'through the Holy Spirit', but we are told that 'Because Joseph, her husband, was a righteous, a just, man and did not want to expose her publicly, he had in mind to divorce her quietly' (Mt 1:19). Why 'quietly'? You might ask as I did when reading the text.

Being 'a just man' means that he was law-abiding. According to the Law of Moses, Joseph would have been required to divorce Mary (Dt 24:1). At worst he could have brought her before a law court where her punishment would have been stoning her to death (Dt 22:23-24). It goes to reason then, that because Joseph was a righteous man he could not overlook Mary's 'sin'. But, exposing her to a public hearing in a law court meant that his 'honour' as a man would be at stake. It would be made known that he had been betrayed and humiliated by the woman promised to him in marriage. In order to save face, Joseph decided to divorce Mary 'quietly'. When the angel of God came to Joseph in a dream and told him not to be afraid to take Mary to be his wife, Joseph changed his mind about divorcing Mary.

[At this point, I interrupted my prepared sermon because I then realised that Joseph's 'normal' understanding of men and women and marriage and sexuality had been interrupted and that he had listened to God's whisper. I put my sermon aside. It was at that moment I knew what had to be done. I claimed the space - in spite of the fact that, as a lay woman, I was a guest invited into that previously (white) male dominated ecclesial space. There I was standing. I could do no other.] (M. Pillay, sermon, 18 December 2018)

25. Especially since Joseph is the focus in Matthew: the angel speaks to him about Mary; it is he that is depicted as an honourable, righteous person and he gets to name the child.

26. Of course, many feminists have also pointed to the objectification of Mary in Luke's Gospel - that even God (ab)uses woman's body (Schaberg 2012); that a woman's worth is understood to be 'in her womb' (Pillay 2008b:213).
This is a paraphrasing of the 'interruption' of my prepared sermon:

Like Joseph, we are sometimes called to 'change our minds' about the way things have always been done. Perhaps, we are called at this time of our church's history, to re-think the way we address clergy - both women and men. Perhaps, we need to be reminded that if we address a woman priest as 'mother' while male priests retain the title 'father', we perpetuate the masculine/feminine dichotomy that ascribes gender-specific roles to men and women. In some parishes, women priests are addressed as 'Reverend'. When I was lay-canon, I had made the suggestion at a Chapter meeting that, perhaps we should consider addressing all priests, irrespective of their gender, as 'Reverend', ${ }^{27}$ I was told then that 'Reverend' is not a title and that it would be grammatically incorrect to address priests as Reverend but that a priest could be referred to as 'The Reverend'. Yet, in that particular diocese, women priests continue to be called 'Reverend' - if not only by their first names - while male priests retain the title 'father'.

As Anglicans, we have to seriously consider the fact that women were refused ordination in the past just because they are women. But, here we are today, witnessing a woman priest celebrate the Eucharist.

[At this point, I acknowledged the woman priest sitting in the sanctuary and returned to my sermon saying, 'now let's take a look at what Mary has to say when, according to Luke, she is addressed by the angel Gabriel as "highly favoured" to be the God-bearer.'] (M. Pillay, sermon, 18 December 2018)

\section{Conclusion: Picking up the thread}

Mary, pregnant and not married, faced an uncertain future. So, according to Luke (1:34), she poses a perfectly reasonable question to the angel Gabriel, 'How will this be, since I'm a virgin?' And Gabriel's answer? 'Nothing is impossible with God' (Lk 1:37). Herein lies our hope even today.

'Hope' turns fear and perplexity into joy - as was the case with Mary who brought 'Hope' into the world. Hope imagines newness. Hope challenges the way things are; the way things have always been done. Hope in God through Christ is not wishful thinking, as fellow Anglican Denise Ackermann reminds us. It means disrupting the same old, same old. In the words of Walter Bruegermann, 'Hope is in the overriding power of God to work a new will against the order of the day'.

I read somewhere that 'hope' as a noun is absent in the gospels, and the verb 'to hope' appears only five times in all of the Gospels. However, 'hope' is present in the person of Jesus who embodies God's promise of a coming kingdom (Jr 23:5-8).

The description of the coming kingdom challenges our complacency (ons tevredenheid) with the powers that be. Any system of power that upholds and justifies control - be it racism, sexism, classism, ageism - is called into question by the hope (newness) inherent in God's kingdom ... which already is, and which is still to come.

Hope (new ways of be-ing) was declared to Mary and Joseph; hope became a reality to those whom Jesus healed, taught and blessed; hope was in the acts and attitudes of those followers who healed and blessed in the name of Jesus; hope is also witnessed by our presence here tonight.

27.'Chapter' is the bishop's advisory council. 
When we receive the bread and wine tonight [from the hands of this woman], let it be the body and blood of Jesus that will awaken something new within us.

During this sacred remembrance (we who are many are one body for we all partake of the one bread), we are liberated to unity (not sameness) in the sacred. Within this communal act, we come with mutual recognition of Christ in the other. We don't come with condescending attitudes of equality but we come realising anew that our lived realities in our marked bodies result in different fears. As Christians, we believe that 'nothing is impossible with God'. Sometimes we, men and women, are called to change our minds like Joseph did; sometimes we, women and men, are called to step forward in boldness like Mary did to become bearers of God in this world. Both are liberating acts. It fosters the birthing of transformation ... that changes our minds and make things new. Amen. (M. Pillay, sermon, 18 December 2018)

In preparing this sermon, I knew I had to interrupt Mathew's Joseph with Luke's Mary, but I had not anticipated that it would be necessary to interrupt my preaching. Perhaps, the disease I felt during the vestment ceremony when the woman priest was addressed as 'mother' and the male priests as 'father' had come from hearing God's whisper. I do not know. What I know is that my lived experience as a woman of faith had prompted me to stand up for others. On the other hand, perhaps what had prompted me to act was the echo of the whisper that went unheard when, introducing the resolution that requested the 1992 Synod of ACSA to give its approval to the ordination of women as priests, the former Dean of St George's Cathedral, Colin Jones (Facebook post, 03 July 2017), poignantly concluded that:

The mass has already been offered by a woman, in a way that none of us, my brothers, can experience. She held a child in her arms and offered him up, saying, "This is my body, this is my blood... ${ }^{28}$ (n.p.)

\section{Acknowledgements Competing interests}

The author declares that she has no financial or personal relationships which may have inappropriately influenced her in writing this article.

\section{Author's contributions}

M.N.P. is the sole author of this research article.

\section{Ethical considerations}

This article followed all ethical standards for a research without direct contact with human or animal subjects.

\section{Funding information}

This research received no specific grant from any funding agency in the public, commercial or non-profit sectors.

28.In 'Hear God calling women', an article in which Revd Mike McCoy quotes Revd Colin Jones. See https://www.facebook.com/pages/category/Religious-Organization/ACSA25th-Anniversary-of-Women-Ordination-to-the-Priesthood-227667387641081/ (viewed 09 August 2019)

\section{Data availability statement}

Data sharing is not applicable to this article as no new data were created or analysed in the study.

\section{Disclaimer}

The views and opinions expressed in this article are those of the author and do not necessarily reflect the official policy or position of any affiliated agency of the author.

\section{References}

Belenky, M.F., Clinchy, B.M., Goldberg, N.R. \& Tarule, J.M., 1986, Women's ways of knowing: The development of self, voice and mind, Basic Books Inc, New York, NY.

Cannon, K., 1994, 'Can we be different but not alienated?', in D. Lois (ed.), Feminist theological ethics, pp. 59-76, Westminister John Knox Press, Louisville, KY.

Cannon, K.G., 1995, Katie's canon, Continuum, New York, NY.

Chitando, E., 2015, 'Reflections in ubuntu and masculinities in the context of sexual and gender-based violence and HIV', in E. Mouton, L. Hansen \& T. Togom (eds.) Living with dignity: African perspectives on gender equality, pp. 269-284, SUN MeDIA, Stellenbosch.

Claassens, L. \& Juliana, M., 2008, 'Interrupting God-language: Rethinking the image of God as liberator in Isaiah 42', in B. Becking \& D. Human (eds.), Exile and suffering, pp. 54-70, Brill, Leiden.

Daly, M., 1973, Beyond God the father: Toward a philosophy of women's liberation, Beacon Press, Boston, MA.

Heckman, S.J., 1990, Gender and knowledge, Polity Press, Cambridge.

Hooks, B., 1994, Teaching to transgress, Routledge, New York, NY.

Nadar, S., 2009, 'Palatable patriarchy and violence against women in SA. Angus Buchan's mighty men's conference as a case study of masculinism', Scriptura 102, 551-561. https://doi.org/10.7833/102-0-614

Oduyoye, M.A., 1997, 'Introduction', in M.A. Oduyoye (ed.), Transforming power: Women in the household of God, pp. 1-6, Sam-Woode Ltd, Accra.

Oduyoye, M.A., 2009, 'Women in ministry: A continuing challenge', in M. Pillay, S Nadar \& C.L. Bruyns (eds.), Ragbag theologies: Essays in honour of Denise $M$ Ackermann: A feminist theologian of Praxis, pp. 29-35, Sun Press, Stellenbosch.

Pillay, M., 2003, 'Women and the church. Solidarity in suffering in the context of HIV/ AIDS', in K. Sporre \& R. Botman (eds.), Building a human rights culture: South African and Swedish, pp. 142-163, Stralins, Falun.

Pillay, M., 2008a, Re-visioning stigma: A socio-rhetorical reading of Luke 10:25-37 in the context of HIV/AIDS in South Africa, Cape Town, viewed 14 July 2019, from https://etd.uwc.ac.za/xmlui/handle/11394/2242.

Pillay, M., 2008b, 'Stigma in the context of HIV.AIDS: Towards integrating individual and societal intervention strategies', in S. De Gruchy, N. Koopman \& S. Stijbos (eds.) From our side: Emerging perspectives on development and ethics, pp. 208-221, From our side: Emerging
Rosenburg, Amsterdam.

Pillay, M., 2012, 'Challenging patriarchal masculinity in "act like a lady. Think like a man": A feminist theo-ethical perspective', in J. Claassens \& S. Viljoen (eds.), Sacred selves: Essays on gender, religion and popular culture, pp. 81-100, Griffel, Cape Town.

Pillay, M., 2013, 'The Anglican church and feminism: Challenging the "patriarchy of our faith"', Journal of Gender and Religion in Southern Africa 19(2), 53-71.

Pillay, M., 2015a, 'Good news for all? A feminist perspective on the gospel of Matthew', Scriptura 114, 1-11. https://doi.org/10.7833/114-0-1127

Pillay, M., 2015b, 'Mighty men, mighty families: A pro-family Christian movement to (re) enforce patriarchal control?', in E. Conradie \& M. Pillay (eds.), Ecclesial reform and deform movements in the South African context, pp. 26-46, SUN MeDIA, Stellenbosch.

Pillay, M.N., 2017, 'Women, priests and the Anglican Church in Southern Africa: Reformation of holy hierarchies', Consensus 38(1), Art. 10.

Prozesky, M., 1990, Christianity in South Africa, Southern Book Publishers, Halfway House, CA.

Robbins, V.K., 1996, Exploring the textures of texts: A guide to ocio-rhetorical interpretation, Trinity Press international, Harrisburg, PA.

Sachs, A., 1998, Annual report of the commission on gender equality, Government printers, Pretoria.

Schaberg, J.D., 2012, 'Gospel of Luke', in C.A. Newsome, S.H. Ringe \& J.E. Lapsley (eds.), Women's bible commentary, pp. 493-511, Westminister John Knox Press, Louisville, KY.

Swart-Russell, P. \& Draper, J., 1991, 'A brief history of the movement for the ordination of women in the church of the porovince of Southern Africa', in D. Achermann, J. Draper \& E. Mashinini (eds.), Women hold up half the sky: Women in the church in Southern Africa, pp. 220-237, Cluster Publications, Pietermaritzburg.

Young, I.M., 1990, Justice and the politics of difference, Princeton University Press, Princeton, NJ.

Van Rheede, L., 2017, Leon van Rheede, viewed 05 July 2017, from https://www. facebook.com/leon.canrheede. 